\title{
CHANGES IN THE NUMBER OF SLOVAKS IN VOJVODINA IN THE LAST HALF CENTURY AND THE IMPACT ON THE SUSTAINABILITY OF SLOVAKIA'S ARCHITECTURAL HERITAGE
}

\author{
Milka Bubalo ŽivkovićA , Bojan Đerčan ${ }^{A}$, Tamara LukićA \\ Received: March14, 2019| Accepted: June 25, 2019 \\ DOI: 10.5937/ZbDght1901029B
}

\begin{abstract}
Slovaks represent an ethnic group which is facing the problem of depopulation. This process is the result of low natural population growth, as well as emigration. In the last three decades, and especially in the last decade, there has been an intensive displacement of the inhabitants of certain ethnic groups who went back to their home countries. The Slovaks began to emigrate in the 1980 s, and this process has been intensified in the last ten years. Although the number of Slovaks in Vojvodina has been reduced, this ethnic group manages to preserve its identity through cultural institutions, ethno houses, various events, magazines, books, radio and television shows in their mother tongue. During this period, when the displacement of Slovaks, as well as members of other ethnic groups, became increasingly intensified the importance of the sustainability of the national identity of ethnic groups in these regions was emphasized. Although the economic situation in Serbia is far from ideal, members of national minorities manage to preserve their customs as well as material goods, i.e. the architectural heritage. The Slovaks collected items that had a different purpose and opened ethno houses, i.e. they renovated and protected the houses that were one, two, and more than two centuries old. It seems that today this custom is even more intensified, as the number of Slovaks in Vojvodina is falling at a high rate.
\end{abstract}

Keywords: Slovaks, depopulation, architectural heritage.

\section{INTRODUCTION}

In Slovakia, the home country of Slovaks living in the area of Vojvodina, there are about 5.5 million inhabitants. About 4.3 million of them are Slovaks. However, the Slovaks live around the world and it is estimated that there are around 2.8 million Slovaks worldwide. Forty years ago, the number of Slovaks in the diaspora was between $1.2 \mathrm{mil}$ -

A University of Novi Sad, Faculty of Sciences, Department of Geography, Tourism and Hotel Management, TrgDositejaObradovića 3, 21000 Novi Sad, Serbia. Contact: milka.bubalo.zivkovic@dgt.uns.ac.rs 
lion and 1.5 million, which indicates a large emigration of the population from this Central European country. Certainly, the political events of the last decades of the twentieth century have influenced the emigration of the Slovaks from their home country. They mostly went overseas or to Western European and other Central European countries (Germany and Austria). Emigration as well as economic development have led to the problem of labor shortage in Slovakia itself. According to experts in Slovakia, at the beginning of last year, there was a shortage of about 80,000 workers. In a short period of time, from the 1990s to this day, Slovakia received a great number of immigrants. A large number of Serbian citizens went to work in Slovakia. Slovaks are leaving Serbia, but Serbs are also leaving. Since 2015, the number of Serbs going to work in Slovakia has reached a number of about 10,000 (Internet 1).

In 2005, the Act on the Slovaks Living Abroad was passed. This Act regulates the status of the emigrated Slovaks, their rights and duties in the territory of Slovakia, as well as the procedure for the recognition of the status of emigrated Slovaks and the functioning of central government bodies in relation to Slovaks living outside Slovakia. Immigrated Slovaks are considered to be those people who are not citizens of the Slovak Republic, those who are Slovaks by citizenship or origin and those who have Slovak cultural and linguistic awareness. A Slovak cultural and linguistic awareness implies passive knowledge of the Slovakian language or an active involvement in the Slovak ethnic community. Slovaks abroad can be divided into those Slovaks and their descendants who ended up outside their home country due to political changes after the collapse of the Austro-Hungarian state. At that time a large number of Slovaks were in the territory of today's Hungary, Serbia, Croatia, Romania, Ukraine and Poland. The second group consists of Slovaks who emigrated in the late $19^{\text {th }}$ century (from Hungary) after World War I and World War II, as well as in the following period, up until today (Internet 1).

The Slovaks have the largest diaspora in the United States - 1,200,000. In Canada there are about 100,000. There are also Slovakians in Argentina, Brazil, Uruguay, Venezuela, Australia, New Zealand, Germany, Austria, France, Great Britain, Serbia, and so on. According to the 2011 Census, there were 52,750 Slovaks in Serbia.

\section{THE MIGRATION OF SLOVAKS TO VOJVODINA}

The migration of the Slovaks to Serbia or Vojvodina is first of all related to the period of Austrian rule, the reign of Charles VI, then the reign of Maria Theresa, and the reign of Emperor Joseph.

The first Slovak immigrants came from the Tatra region to Bačka, mostly due to the persecution of protesters, i.e. around 1720 during the reign of Charles VI. First, they settled in Bajša. In 1740, they emigrated to Petrovac. During the rule of Maria Theresa, in 1742 , they came to Bezdan. Dissatisfied with the amount of land they received, one part of this population moved to Srem where they received vineyards. However, vineyards were most often converted into arable land, since they mostly did not have experience with wine growing in their home country. In 1740, Futog was settled by the Slovakian farmers of the Evangelical Faith who came from various parts of the northern Hungari- 
an and Pest County. Two decades later, the Archbishop of Kaloča, Adam Patačić, settled 120 Slovakian families of the of the Evangelical religion on his property in Bač-Selenča in Bačka, but he wanted to convert them into the Roman Catholic faith. However, he did not succeed because they moved out of the settlement and settled in Stara Pazova, where they named the village street Selenačka. Stara Pazova was an old village inhabited by the largest number of Licaners. In addition to these Slovaks, who settled in Jan Bon on the territory of Vojvodina, some other inhabitants from Pest, Zvolen, Lipovci and the Turkic counties came to settle in later years.

The Slovaks settled in Petrovac in 1745. More intensive immigration took place in 1783 during the reign of Josef II. Those people were from Pest, Zvonen, Turkic and New Belgrade. In addition to Petrovac, they also migrated to Gložan, Veprovac (Kruščić), Kisač and Topola (Backa Topola). At the same time, a further number of Slovaks of the evangelical religion in Bajš came to settle. A number of Slovaks settled in Pivnice (17901791) and Stara Pazova (1792). The Slovaks also came to live in Novi Slankamen during Josip II, 1793 (Gavrilović, 1971a).

In Banat, the Slovaks were first settled near Modoš (Jaša Tomić). During the reign of Josef II, a thousand Slovaks from Northern Hungary (1784-1787) were settled. In search of better living conditions, these Slovaks moved to Aradac and Ečka in 1788. However, due to the Ottoman expansion up to the middle Banat, which occurred in 1788, these Slovaks were mostly displaced. Some went to Lalić, and many settled in the Military Border. In addition to the Ottoman expansion, their displacement was also affected by the bad position of workers on the Sipahi estate, but also the plague that many Slovaks succumbed to (Jankulov, 1961, Gavrilović 1971b).

The Slovaks continued to settle on the territory of Vojvodina throughout the $19^{\text {th }}$ century. Valuable, persistent, and satisfied with little food, the Slovaks were considered to be the best colonists by the Hungarian authorities. In addition, they were good immigrants who fitted into the Hungarian colonization plan and also for cultural and political reasons. Their co-operation in the hungarianization, and their rapid merging with the Hungarians, were satisfactory to Pest.

In the second half of the $19^{\text {th }}$ century, the Slovaks were settled along with the Hungarians, the Germans, the Bunjevci and the Šokci in the Silađi colony near Apatin. In that period, the Slovaks were settled in Srem, where they came mainly from Bačka. Then, about 20 families came to live in the settlement Grk (Višnjićevo).

A significantly larger number of Slovaks was recorded in Banat in the $19^{\text {th }}$ century. About 1800, the Slovaks settled in Kovačica, and in 1806 and 1809 in the neighboring Padina.

According to the decision brought on by the General Command, September 17, 1800, four new districts were to be established at Banat Military District, the first onein Nova Rabanda and Maksimova, the second one in Ilačinka, Patinka, Dobrinka, VelikaCrepaja and Zeldoš, the third one in Kovačicaand Nova Debeljača; and the fourth one in Poprešić and Mali Alibunar. Thus, Slovak settlements were built and named after Prince Anton - Antalfalva (now Kovačica), followed by Karlsdorf, Janosfalva (later called Lajosfalva, today Padina) and Francfeld. 
The Slovaks who settled in Kovačica in the period from 1801 to 1802 came from Orava, Trenčín, Békés and Pest County and one part from Ečka. They came to Padina in 1806 from the Liptov, Gemer, Nógrádand Pest County. The Slovakians moved from Dvorto Dusanovac in 1825. In 1830 the tenant Lajos Barah settled the Slovaks in StariLec. They were settled in 1868 beside the Germans in the Marijenfeld settlement near Pancevo. However, due to a catastrophic flood, they moved to the Hungarians in Vojlovica. At the same time, they settled alongside the Germans and Bulgarians in Ivanovo near Kovin (Jankulov, 1961).

With all these movements and relocations, it is difficult to speak of the exact number of the Slovak population. Relatively reliable data exist only since 1900 when the official Hungarian statistics recorded 30,002 Slovaks in Bačka, 14,969 in Banat, and 11,415 in Srem. Therefore, at that time, in Vojvodina there were 56,386 inhabitants who declared themselves as Slovaks.

The Slovakian population that came to the territory of today's Vojvodina in the above mentioned periods were mostly peasants - farmers. This fact has long marked the life of this population in the new homeland, which was abandoned to a large extent after the departure of the Ottomans. According to the research done by Jan Siricki (1972), the main reasons for the emigration of the Slovaks were religious persecutions (the Slovak population of evangelical religion were mostly exposed to these persecutions), but also social feudal oppression and exploitation.

At the time of the most intensive resettlement of the Slovaks to the southern parts of the Kingdom of Hungary, in the "Lower Country", The Slovaks in their home country, as well as those in the "Lower Country", lived in one state. It was so until 1918, when the Slovaks in the "Lower Country", together with the Serbs, won the accession of Vojvodina to the newly formed state of the Kingdom of Serbs, Croats and Slovenes. That year was a milestone in the life of the Slovaks, because on the one hand they were removed from their motherland, and on the other hand they gained more favorable conditions for their national and cultural development. Soon afterwards, in 1919, the Slovakian Gymnasium was established in Bački Petrovac, and in 1928 the Slovak National Home was founded in Stara Pazova (Siricki, 1972).

The Slovaks moved to Vojvodina intending to acquire the arable land, which they did not have due to the fact that they were dependent peasants in their home country. In the first two, three decades after settling into these areas, they were concentrated on the agriculture, the construction of houses and their own general settlement in the new environment. Adapting to the new environment was difficult and long-lasting. A desire to fit into the ethnic colony of this region and gain economic stability was highly prominent. What is particularly characteristic of the Slovak ethnic group living on this territory is the fact that although they were adapting to the new environment, at the same time they managed to stay closed as an ethnic group. This has contributed to the preservation of their folk tradition and language. Such a way of life also encouraged distrust of everything that is new and unfamiliar as well as everything that is beyond the boundaries of one's own peasant world.

The evangelical church also had great significance and role in the survival and preservation of its own traditions and culture of Slovakia. It fought against violent denation- 
alization during the Austro-Hungarian period. The Evangelical Church had a major influence through numerous schools and spreading education.

\section{DEMOGRAPHIC TRENDS OF THE SLOVAKS LIVING IN VOJVODINA}

In the area of former Yugoslavia, the largest number of Slovaks lived in Vojvodina. After the Second World War, according to the Census of 1948, there were 83,626 Slovaks in former Yugoslavia, of which 72,032 were settled in Vojvodina (86.1\%). A large number of them were still in Croatia $(10,097)$ where they were mostly concentrated in Slavonia. And these are precisely the areas that used to be the southern parts of the Kingdom of Hungary where Slovaks settled during the 18 and $19^{\text {th }}$-century migrations. The Slovaks made up only $0.5 \%$ of the total population of the former Yugoslavia, and in Vojvodina they accounted for $4.3 \%$ of the population. Population figures in 1961 show the highest number of Slovaks in the former Yugoslavia $(86,432$ persons or $0.5 \%$ of the total population of the SFRY). Also, in 1961, the largest number of Slovaks could be found in Vojvodina - 75,333 (Table 1). By the end of the 1960s, they accounted for slightly more than $4 \%$ of the total population in Vojvodina. Since the 1970s, there has been a slight decline in both the absolute and the relative number of Slovaks in Vojvodina and throughout Serbia.

Still, the largest number of Slovaks lives in Vojvodina, taking into account the complete territory of Serbia. In 2011, there were 50,321 Slovaks in Vojvodina, accounting for $95.4 \%$ of the total number of Slovaks in the Republic of Serbia. There is still a slightly higher number of Slovaks living in the Belgrade region, while an extremely small number of Slovaks lives in the other parts of Serbia (Table 2).

It is difficult to compare data by municipalities in the area of Vojvodina in a longer period of time, due to the change of the census units after the Second World War, as well as the territorial changes. According to the censuses of 1948 and 1953, the data were published according to the regions, and since 1961 the data is available according to the municipalities. Thus, Table 3 shows the changes in the number of Slovaks by municipalities in Vojvo-

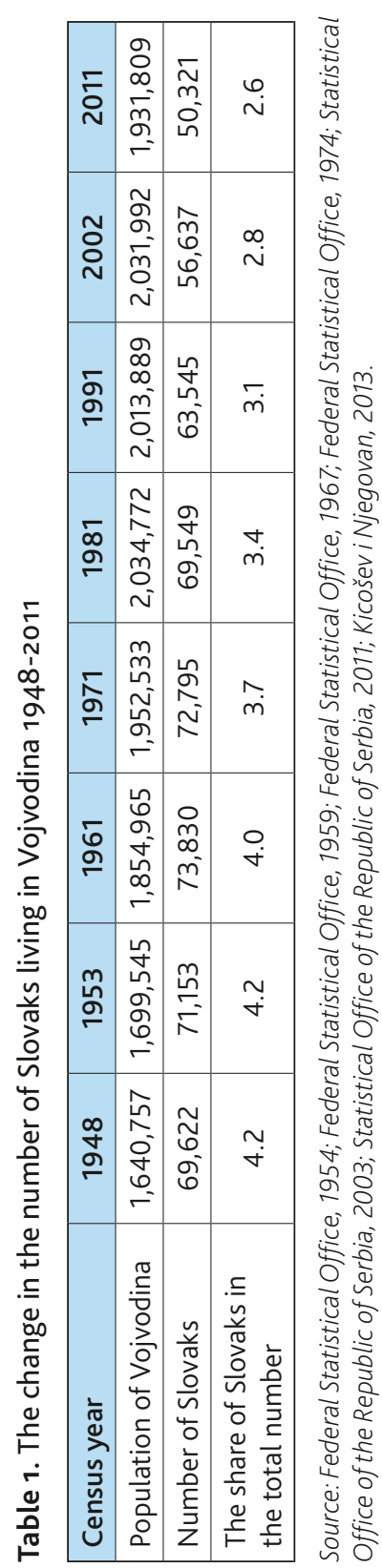


Table 2. Spatial distribution of Slovaks in the Republic of Serbia by regions, according to the 2011 Census

\begin{tabular}{|c|c|c|c|}
\hline \multicolumn{2}{|c|}{ Serbia - North } & \multicolumn{2}{|c|}{ Serbia - South } \\
\hline \multicolumn{2}{|c|}{52,425} & \multicolumn{2}{|c|}{325} \\
\hline \multicolumn{2}{|c|}{99.4} & \multicolumn{2}{|c|}{0.6} \\
\hline Belgrade Region & Vojvodina Region & $\begin{array}{l}\text { The region of Šumadija } \\
\text { and Western Serbia }\end{array}$ & $\begin{array}{l}\text { Region of South and } \\
\text { East Serbia }\end{array}$ \\
\hline 2,104 & 50,321 & 164 & 161 \\
\hline 4.0 & 95.4 & 0.3 & 0.3 \\
\hline
\end{tabular}

Source: Statistical Office of the Republic of Serbia, 2011.

dina and their share in the total population of those municipalities in the period from 1961 to 2011.

The decline in the number of Slovaks during a period of fifty years is evident in almost all municipalities. In some municipalities there was a certain increase in the number of Slovaks between the censuses of1961 and 1971. However, the increase was not significantly high. Since 1971, in all municipalities, the number of Slovaks has been reduced, which is a consequence of low birth rate characteristic for all ethnic groups in Vojvodina. In addition to that, the decline in the number of inhabitants is a consequence of the emigration, which began in the 1980 s, and continued throughout the $21^{\text {st }}$ century, especially in its second decade. These are repatriations, i.e. descendants of former immigrants to the territory of present-day Vojvodina return to their home country after two and a half centuries. Wartime developments in Serbia in the 1990s and economic problems since the end of the 20th century led to the relocation of the Slovaks from Serbia to Slovakia. Such migrations have been particularly intensified from 2015 to the present (Zlatanović and Marušiak, 2017). Some authors call these migrations co-ethnic, because the immigrants are of the same ethnicity as the inhabitants of the place to which they relocate. Bearing in mind this feature, this migration belongs to the category of ethnically-privileged ones (Müns \& Ohliger, 1997; Čapo Žmegač, 2005), due to the fact that migrants return to their ancestors' places.

An additional demographic problem is the rise in the mean age of this ethnic group. Between the last two censuses (2002 and 2011), the mean age of the Slovaks increased from 41.9 to 44.0 years. In some municipalities, the mean age of the population of this ethnic group in 2011 was over 50 years old (Bubalo Živković, 2017, Plavša and BubaloŽivković, 2006). All this points to the problem of intensive aging of this ethnic group, as well as others in Serbia.

In the municipalities of Bački Petrovac, Bačka Palanka, Kovačica, Novi Sad, Stara Pazova and Šid there is the largest number of Slovaks living in Vojvodina. The relative number of Slovaks is the highest in Bački Petrovac (65.4\%), Kovačica (41.8\%) and Bač (19.8\%) (Table 3). In the municipality of Backi Petrovac, the largest number of Slovaks live in the settlement that carries the same name, followed by the settlements of Gložan and Kulpin. In the municipality of Bačka Palanka, the majority of them can be found in the center of the municipality, followed by Pivnica and Silbaš. The Slovaks inhabit the 


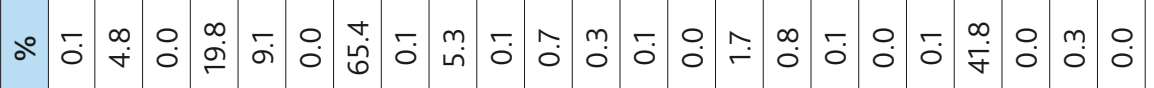

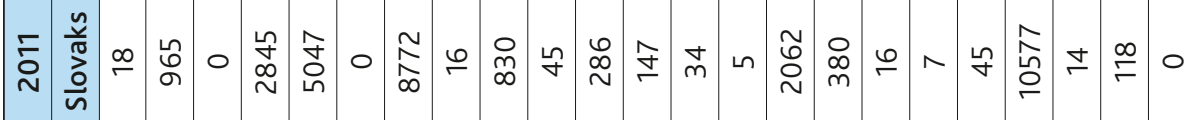

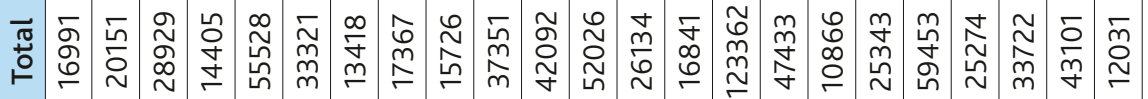

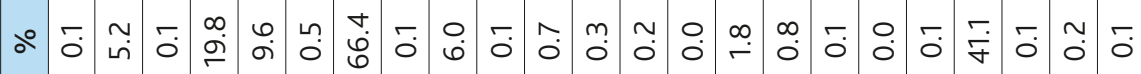

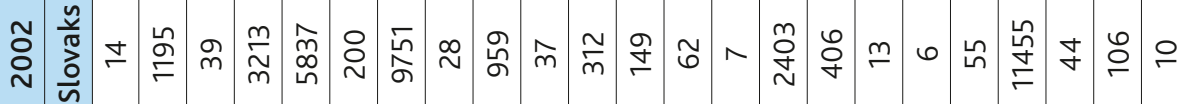

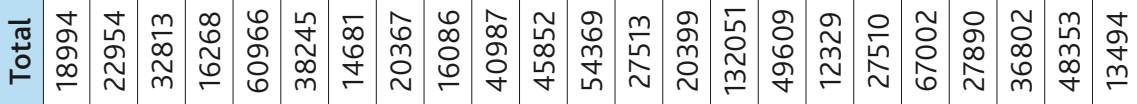

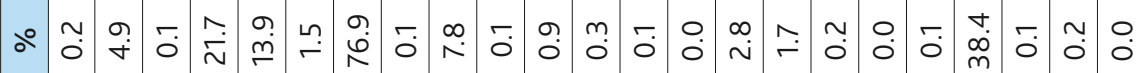

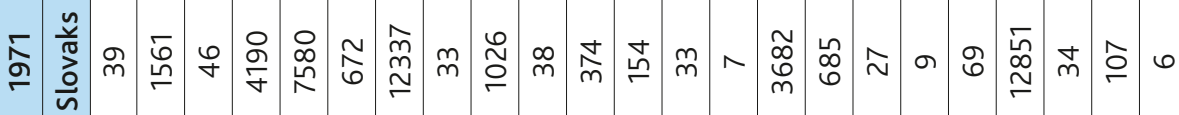

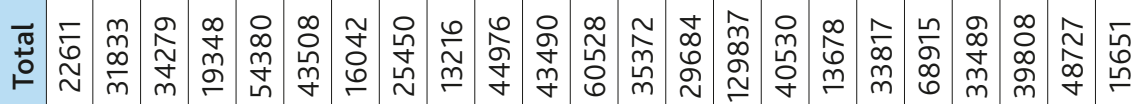

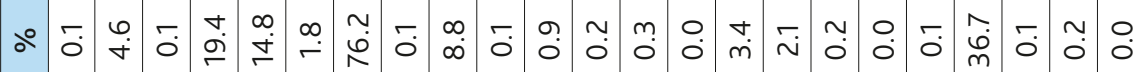

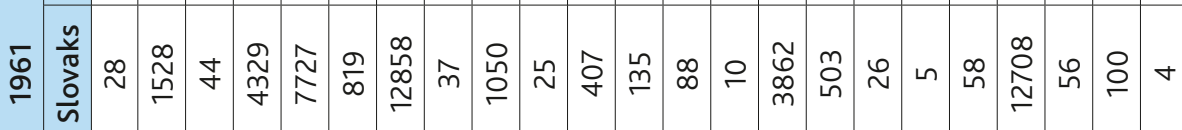

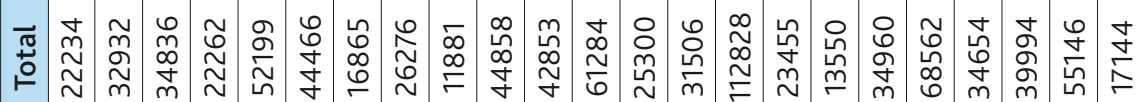

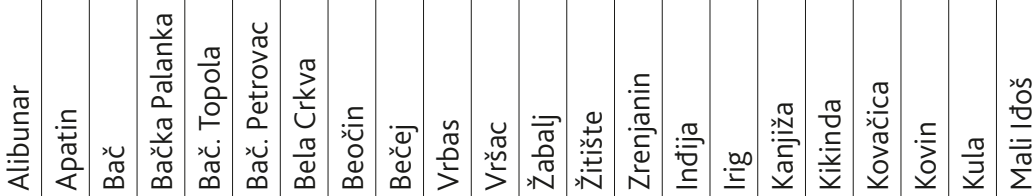




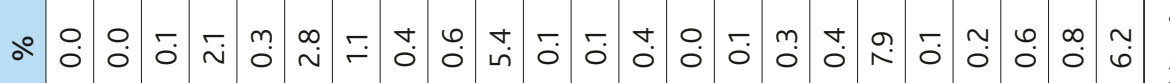

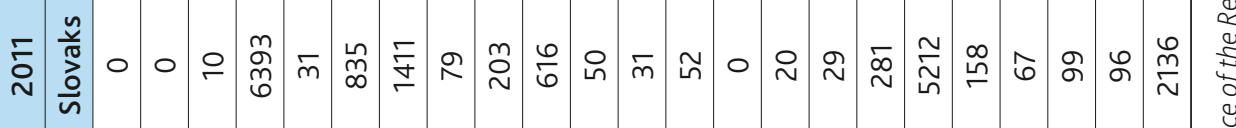

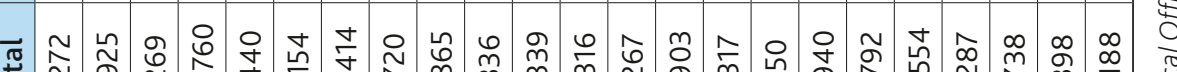

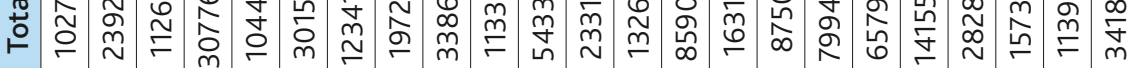

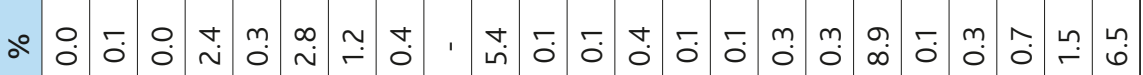

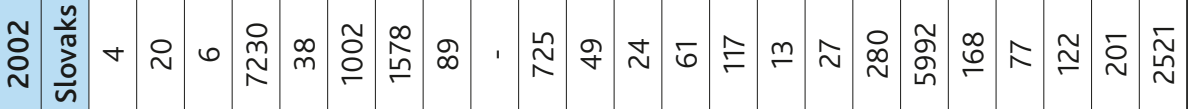

テ

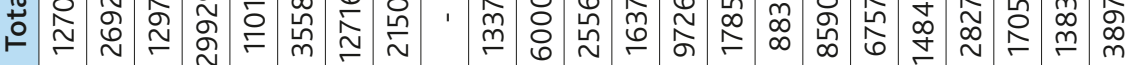

ஃ

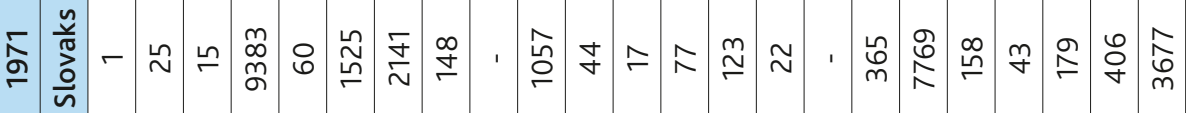

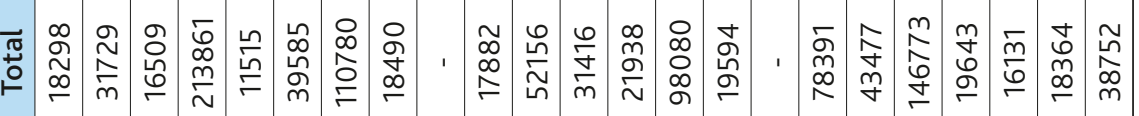

م

过

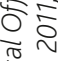

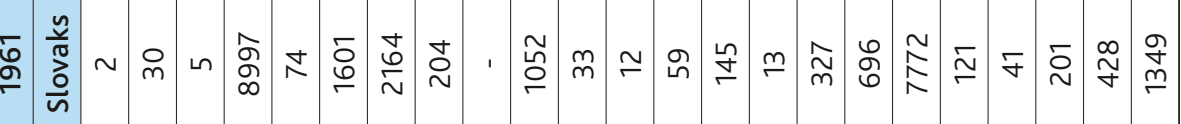

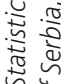

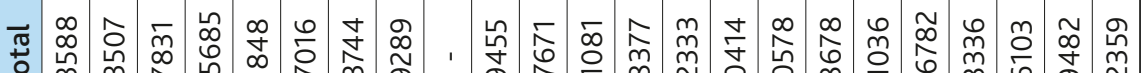

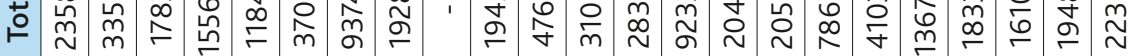

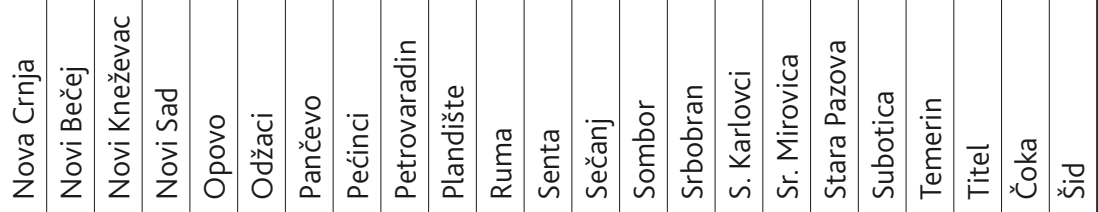

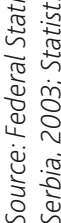


center of municipality of Kovačica, as well as Padina. In the municipality of Novi Sad, a large number of Slovaks are settled in Kisač, in addition to the center of the municipality. In Srem municipalities, the Slovaks live in the center of the municipality Stara Pazova and in the center of Šid municipality. In addition to these settlements, a large number occupy the settlements of the Šid municipality: Bingula, Erdevik and Ljuba. In the municipality of Beočin, the Slovaks make up the majority of the population in Lug. There is a great number of Slovaks in Bačka, mainly in Lalić, the municipality of Odžaci, and in the village of Selenča, municipality of Bač. There is a certain number of Slovaks in Banat- in Janošik (Alibunar municipality), Aradac, Belo Blato and Zrenjanin (Zrenjanin municipality).

The entry of Slovakia into the European Union, followed by the global economic crisis (2008), economic problems and political instability have affected and will continue to affect the emigration of Slovaks from Serbia, which will lead to an additional fall in the number of members of this population and an increase in mean age. In such a situation, it is necessary for the Slovak ethnic community to preserve its identity in Vojvodina, as it has done to date. In the research conducted by Zlatanović and Marušiak (2017), many Slovaks are concerned about the survival of their community in Serbia, since young and educated people are the ones who leave. However, there are those who look on the bright side and believe that the movement of people, information and different forms of goods are necessary for the development and sustainability of an ethnic group in a certain area (Boccagni, 2016).

In two and a half centuries, the Slovaks managed to preserve their cultural identity, language, customs, material assets, architecture, and artistic heritage. Due to the decreasing number and aging of the Slovakian population in Vojvodina, it is necessary to preserve the material and spiritual values of this ethnic group, which will lead to their sustainability regardless of their number.

\section{THE ARCHITECTURAL HERITAGE OF THE SLOVAKS IN VOJVODINA}

As the third largest ethnic group in Vojvodina, the Slovaks managed to preserve their identity, customs, folk costume, and language. Numerous Slovak houses have been preserved, some of which are more than two centuries old. Some of them were converted into ethno houses (in Padina, Vojlovica, Bajša, Bački Petrovac, Kovačica, Hajdučica, Silbaš, Lalić), where they collected and preserved items used by their ancestors, inside the house or in the agriculture. Slovak ethno houses, as well as ethnic houses of other ethnic groups in Vojvodina, built in the traditional style of folk architecture of Vojvodina (Todorović, Bjeljac, 2007), are quite similar, because of the same or similar construction, but they have elements of something individual, characteristic of certain ethnic groups. This individuality is most often reflected in the house furnishing ideas, commonly used colors, patterns, decorations that differ among Serbs, Slovaks, Hungarians, as well as other ethnic groups.

The Slovakian national architecture in Vojvodina was probably under the influence of the southern Slovakia builders, but it was conditioned by the natural and social factors 
met by the Slovaks upon coming to the area of Lower Land. Due to the different materials they encountered, they built houses which differed from those they left behind in Slovakia. The construction, form and material were adapted according to the need and application.

The oldest Slovak house on the territory of Vojvodina is the Native Country House in Bački Petrovac, which was built in the second half of the 18th century and represents the traditional residence of the first Slovaks settled in Vojvodina (Jovanović-Gudurić, 2018). The house was declared a cultural monument of exceptional importance in 1965 (Internet 2). It belongs to the transitional stage in the development of Pannonian type of construction. It does not belong to the pit-house category. However, it is partially subterranean as there are several descending steps at the entrance. It was built from the rammed earth and covered with reed. Apart from this house, in villages with the Slovak population, a large number of $19^{\text {th }}$ century houses that are not under the protection of the
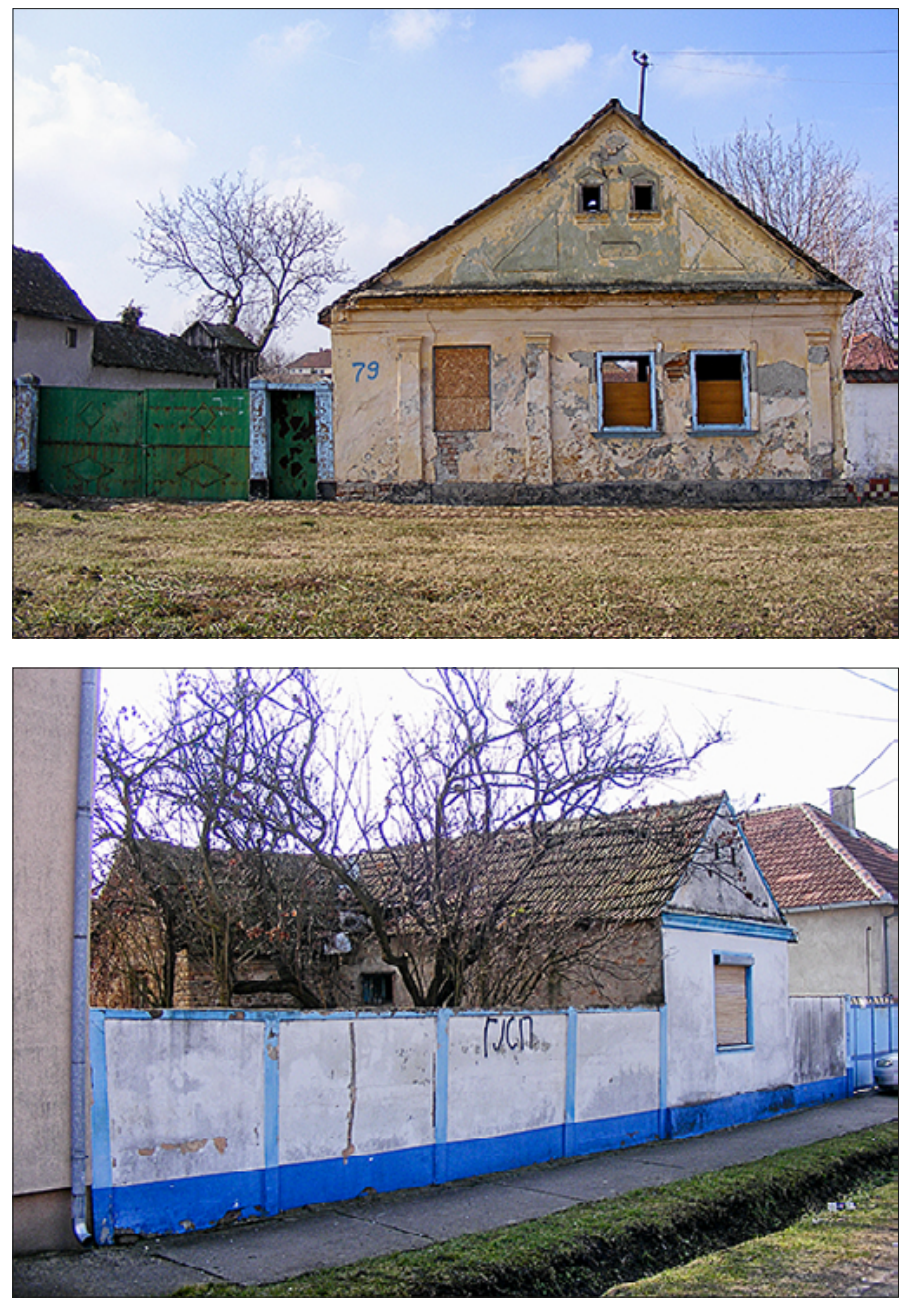

Figures 1 and 2. Abandoned Slovakian houses in Stara Pazova Source: Author 
state are exposed the ravages of time, and some of them are abandoned (Figures 1 and 2 ), which is the consequence of the emigration of their owners to larger centers in Serbia, Slovakia, West European countries or overseas countries.

Slovakian construction visually differs from the traditional houses of other ethnic groups in Vojvodina, but the form, plan and purpose are almost the same in all Vojvodina houses. There are some differences, however, they are minimal. Thus, the Slovakian house is recognizable because the color blue was used to decorate the façade (Figure 3). In addition to blue, which has been used in more shades, light to dark blue, other colors can also be found, such as light green. Apart from painting the facade of houses, the Slovaks often resorted to gluing ceramic tiles around the house, mostly in blue and white, but other colors can also be found. Houses that were decorated with ceramic tiles were most often built after the Second World War and they have a form similar to other houses that were built at the time. Façade is the only feature that distinguishes Slovakian houses in relation to the houses of other ethnic groups.

In addition to the blue color, the Slovaks use light green, such as the painted facade of the ethno house in Lalić, even white (Figure 6) or some other color. During the construction of new houses, some Slovaks use ceramic tiles to decorate the façade, even for the storey houses (figure 7).

The interior of the Slovakian house did not differ from other houses in Vojvodina, especially the attached/terraced houses. The layout of the rooms was the same (Figure 8) and they developed the same as with other ethnic groups. The oldest houses had a front room (predna izba) and a back room (zadna izba), and between them there was a kitch-

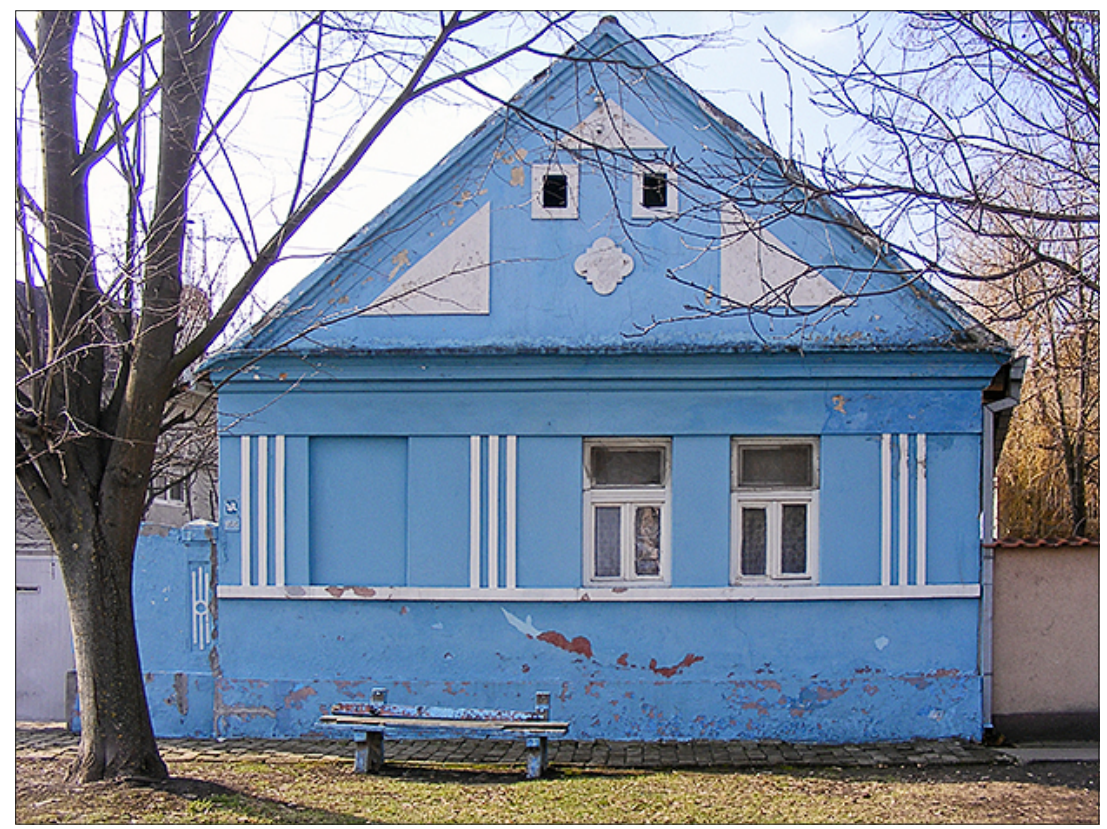

Figure 3. Slovakian house built before the Second World War 

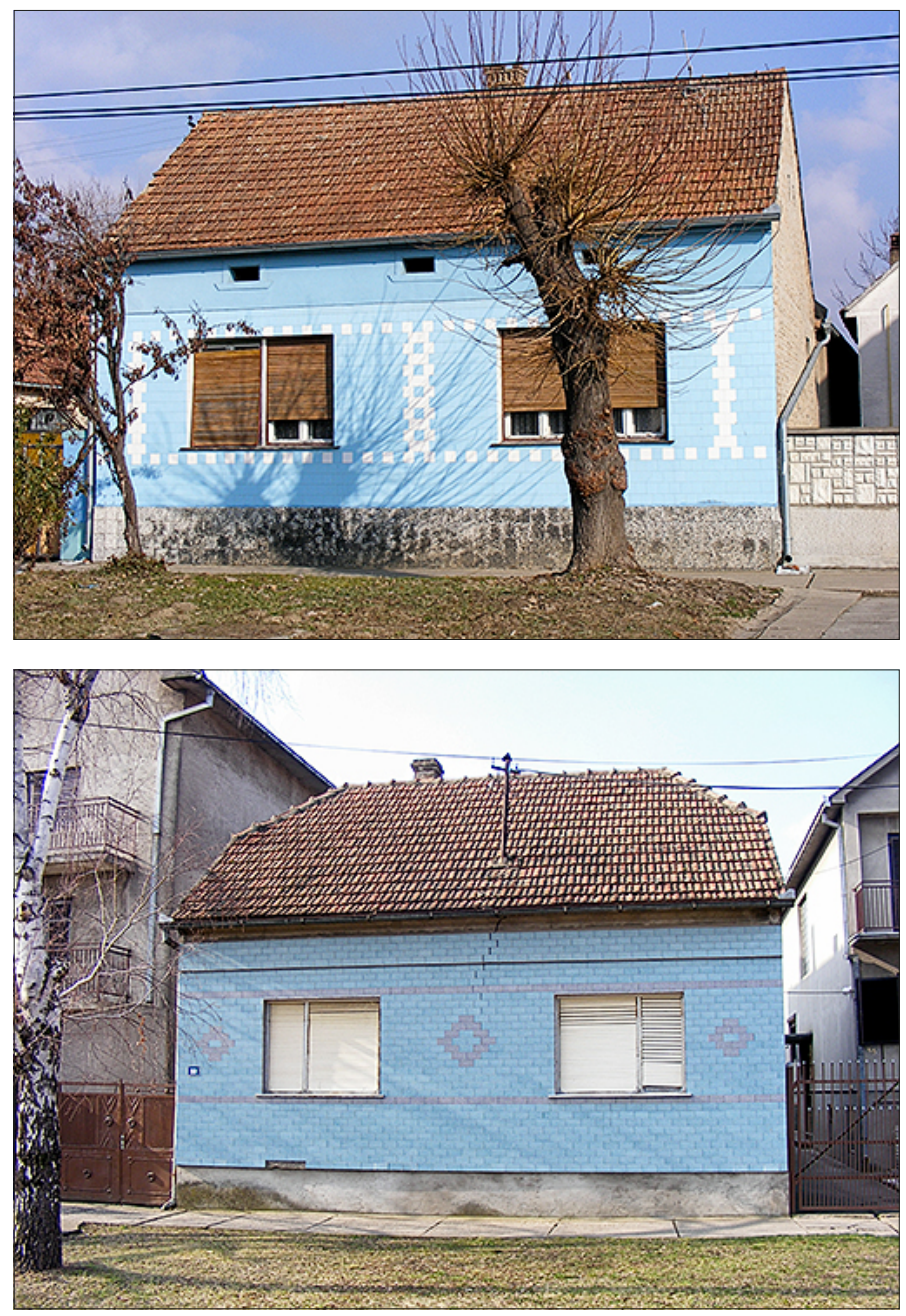

Figures 4 and 5 . Facades of Slovakian houses decorated with ceramic tiles Source: Author

en (pitvor). Newer houses that were built after the Second World War, as well as the most recent ones, were built using plans that were used by the other nations as well. Some of them are distinguished, as it is written, only by the characteristic Slovak facade.

Since the Slovaks who were settled in Vojvodina were mostly farmers and cattle breeders, the economic buildings, i.e. the auxiliary facilities, were the same as others Vojvodina. It was the basic type of house. In the extension of the house, towards the garden, there were the shed (ciena), blockhouse for agricultural products (čardak), and stables (chlievy). In the middle of the yard there was a well with a valve for feeding livestock. In the yard there were stables, a summer shed, and a garden.

When it comes to newer houses, the layout of auxiliary facilities and ancillary buildings is no different from those of other ethnic groups. It only depends on the occupation of the people who live in those houses. 

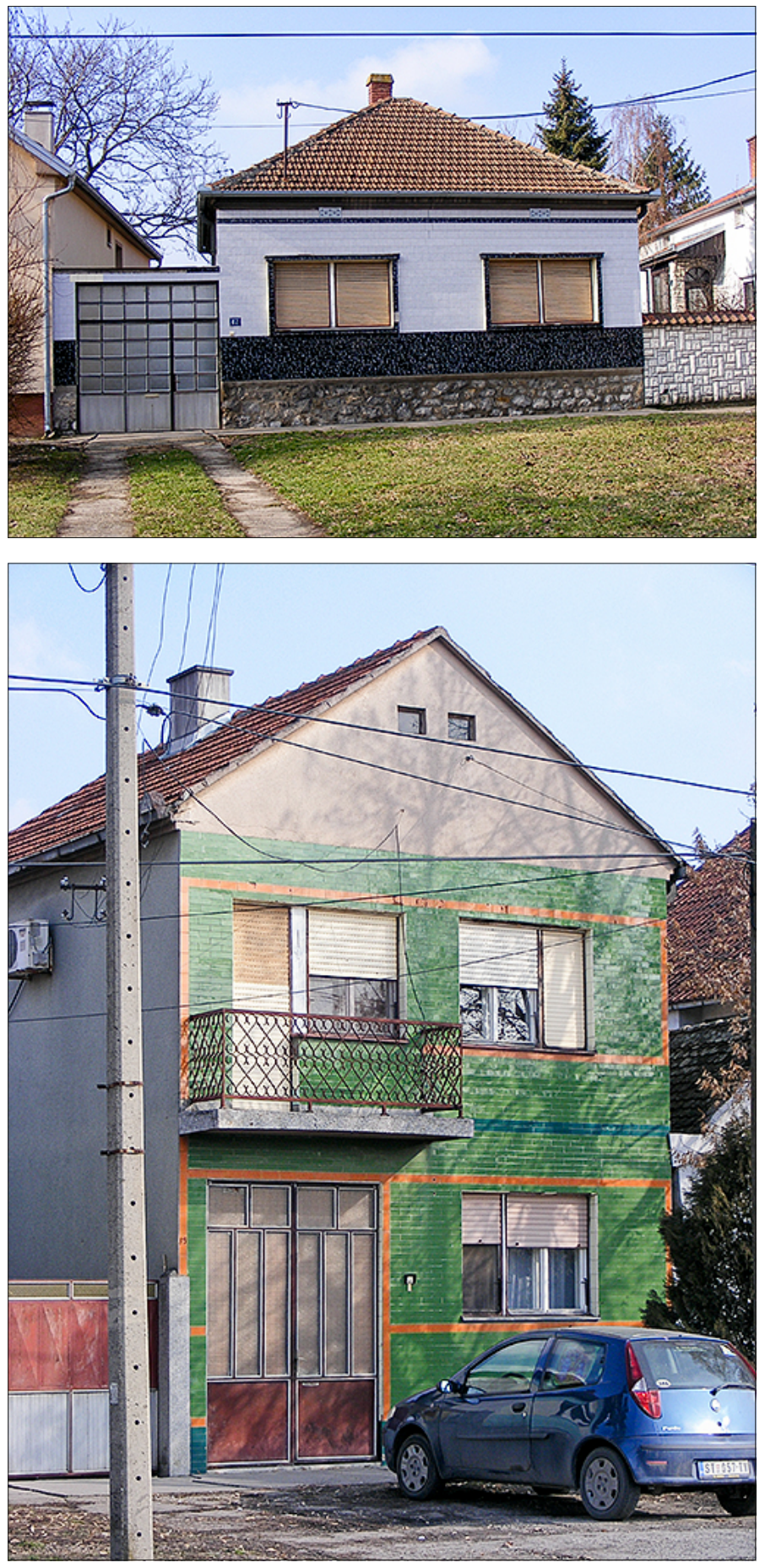

Figures 6 and 7. A new Slovak house decorated with ceramic tile Source: Author 


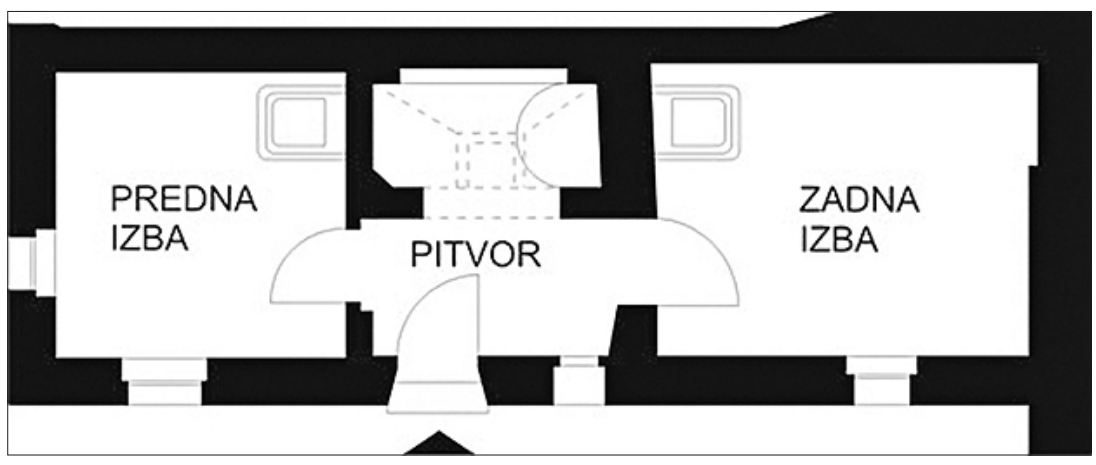

Figure 8. The layout of the rooms in the older Slovakian houses

Source: Internet 3

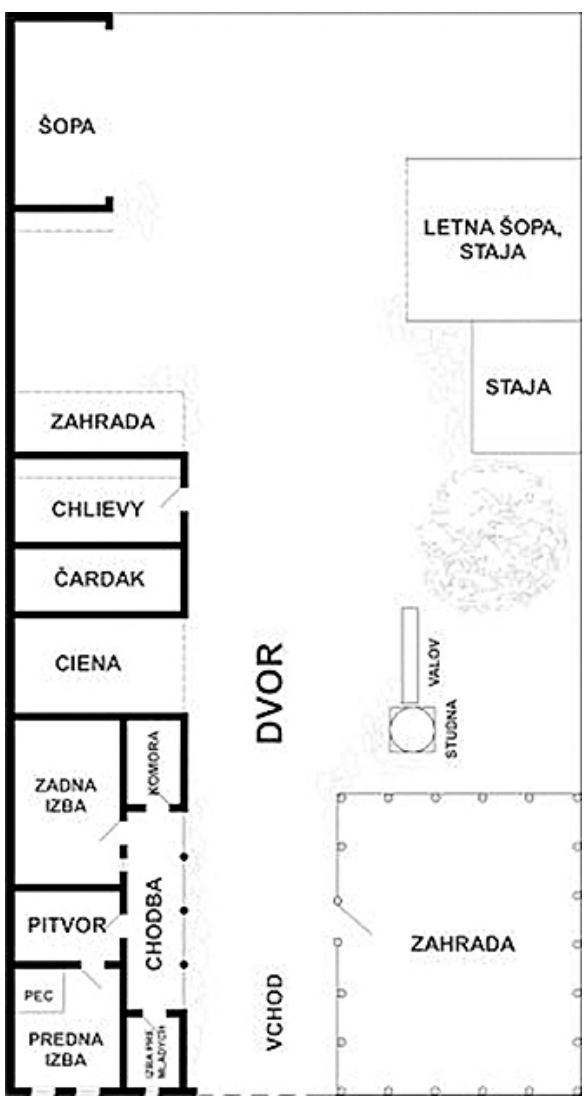

Figure 9. Auxiliary rooms and economic buildings in the Slovakian house yard Source: Internet 3

During the last years of the $20^{\text {th }}$ century and first decades of $21^{\text {st }}$ century, the formation of ethno houses of some of the national minorities in Vojvodina arose from the need to rebuild the identity. The emphasis on the identity and diversity of ethnic groups 
among those groups and even within the same ethnic group is a reaction to the globalization process (Gavrilović, 2008). In this way, the Slovaks are trying to preserve material objects and entire buildings, but also many spiritual values that they have acquired in the area of the Lower Land in the past two and a half centuries.

\section{CONCLUSION}

Slovaks who still live in Vojvodina are considered to be a living branch of the Slovak people. Out of all Slovaks living in the Diaspora, the Slovaks in Vojvodina, after two centuries of migration, managed to maintain their national consciousness, the language of their ancestors, as well as various characteristic lines of material and spiritual culture in the best possible way. Today, they create literary works, textbooks, newspapers and magazines in their mother tongue, as well as they used to, and have their own radio and television shows. For more than two centuries, they kept their community quite closed. However, at the end of the $20^{\text {th }}$ century, their community started to open. The inaccessibility of this group has often led to genetic changes in their descendants. On the other hand, they preserved their customs and costumes. Their language managed to resist the influence of the language of the people they lived with. Nevertheless, according to the experience of the Slovaks who immigrated to Slovakia in the last decades, the language of Slovaks in Serbia was to a certain extent exposed to the influence of other nationalities in this area. Thus, it adopted the words of the Serbian language, but also of other nations.

When it comes to the architectural heritage of the Slovaks in Vojvodina, it does not differ much from the architectural heritage of the Serbs as well as other ethnic groups because they all lived together under the influence of the same natural and social factors and all had the same dominant material for building houses and ancillary buildings. Also, the structures of their agricultural estates don't differ as well. The only difference that distinguishes the Slovaks, when considering the architectural heritage, is the use of dominant colors in the façade and the interior decorations. Blue color dominates. In the interior, floral wall paintings can often be found. The facades of houses that were built after the Second World War were most often decorated with ceramic tiles. Even today, the houses are being decorated with ceramic tiles. However, in this case, other colors are used.

Slovaks tried to preserve their uniqueness in this area by forming cultural institutions, homeland homes, and in the last few decades ethno houses, which are characteristic of other nations as well, are formed. There are cases in Vojvodina where one ethno house actually represents several ethnic groups -rooms are dedicated to different ethnic groups living in the same settlement. This is possible, precisely because all ethnical groups living in Vojvodina have similar houses.

The impression is that the number of Slovakian ethno houses, as well as ethno houses of other ethnic groups, has been increased, especially since the number of inhabitants in almost all ethnic groups has been reduced. Thus, they are showing a tendency to preserve the identity at the moment when their community is losing its members. On the other hand, they are opposing the process of globalization where there are no differences and every one is a part of the whole. 
Today, when there is an increasing number of Slovaks, which will only be shown in the next census in 2021, due to the intensive emigration of the last decade, and also due to the low natural increase of the population in the area of Vojvodina, it is necessary to emphasize and preserve the uniqueness of this area. This is precisely what makes Vojvodina unique and rich, not as much materially, but spiritually.

\section{ACKNOWLEDGEMENTS}

The authors would like to express their sincere thanks to the Provincial Secretariat for Higher Education and Scientific Research of the Vojvodina Province, Republic of Serbia (Project No. 142-451-2686/2018-01), for their financial support.

\section{REFERENCES}

Boccagni, P. (2016). From the multi-sited to the in-between: ethnography as a way of delving into migrants' transnational relationships. International Journal of Social Research Metodology, 19/1, pp. 1-16.

Bubalo Živković, M. (2017). Starost etničkih grupa na prostoru Vojvodine. U monografiji: Etničke grupe Vojvodine u 21. veku - stanje i perspektive održivosti. Univerzitet u Novom Sadu, Prirodno-matematički fakultet, Departman za geografiju, turizam i hotelijerstvo, str. 18-45.

Čapo Žmegač, J. (2005). Ethnically privileged migrants in their new homeland. Journal of Refugee Studies, 18/2, pp. 199-2015.

Đekić, M.(1994).Kuća kao spomenik kulture. Pokrajinski zavod za zaštitu spomenika kulture, Novi Sad.

Federal Statistical Office (1954). Population by nationality. Final census results of March 1948, Book IX, Belgrade.

Federal Statistical Office (1959). Nationality and mother tongue. Population census in 1953, Book VIII, Data by regions according to the administrative division in 1953 , Belgrade.

Federal Statistical Office (1967). Vital, ethnic and migration features. Population Census 1961. Book VI, results for municipalities, Belgrade.

Federal Statistical Office (1974). Ethnic, educational and economic characteristics of the population and households according to the number of members. Census of Population and Housing 1971, Volume VI, Belgrade.

Gavrilović, LJ. (2008). Etno kuća: u potrazi za identitetom. Muzeji, br. 1, str. 135-146.

Gavrilović, S.(1971a).Statističkipodaci o SlovacimaiNemcima u BačkojiSremu 1818. godine. Zbornik za istoriju, Matica srpska, br. 4, str. 119-120.

Gavrilović, S.(1971b).NaseljavanjeSlovaka u Novi Slankamen (1791). Zbornik za istoriju, Matica srpska, br. 3, str. 105-108. 
Jankulov, B. (1961).PregledkolonizacijeVojvodine u XVIII i XIX veku. PosebnoizdanjeMaticesrpske, Novi Sad.

Jovanović-Gudurić, I. (2018). Etno-kuće i kompleksi u sastavu muzejskih ustanova u Srbiji. Zbornik radova sa naučnog skupa održanog 11. aprila 2017. godine „Etno-sela i seoske ambijentalne celine u Republici Srbiji i Republici Srpskoj", SANU, knjiga CLXIX, Beograd, str. 67-84.

Kicošev, S., Njegovan, D. (2013). Razvoj etničke i verske strukture u Vojvodini, MID.

Müns, R., Ohliger, R.(1997). Deutsche Minderheiten in Osmittel - und Osteuropa, Aussiedler in Deutschland. Eine Analyse ethnisch privilegierter Migration. Demographie aktuell 9. Humbolt - Universität zu Berlin.

Plavša, J., Bubalo-Živković, M.(2006). Ko je najstariji u Vojvodini? Zbornik Matice srpske za društvene nauke, br. 121, str. 282-291.

Siricki, J. (1972).Slovaci u Vojvodinikaoistorijsko-etnografskifenomen. Zbornik za istoriju, Matica srpska, 5, str. 109-118.

Statistical Office of the Republic of Serbia, 2003, National or ethnic affiliation. Census of Population, Households and Flats in 2002, Volume 1, Belgrade.

Statistical Office of the Republic of Serbia, 2012, Ethnicity. Data by municipalities and cities, Census of Population, Households and Housing 2011 in the Republic of Serbia, Book 1, Belgrade.

Todorović, M., Bjeljac, Ž. (2007). Osnove razvoja ruralnog turizma u Srbiji. Glasnik SGD, sv. LXXXVII-br. 1, str. 135-148.

Zlatanović, S., Marušiak, J.(2017). „Povratne“ migracije vojvođanskih Slovaka i pitanje pripadnosti. Glasnik Etnografskog instituta SANU, LXV (3), str. 653-668.

$$
\propto
$$

Internet 1: https://slovake.eu/hr/intro/language/slovaks

Internet 2: http://spomenicikulture.mi.sanu.ac.rs/spomenik.php?id=647

Internet 3: http://www.slovackizavod.org.rs/sr/kulturno-nasledje/1372 